\title{
Prof.Dr. Ahmed Yüksel Özemre’nin Tasavvufî Görüşleri
}

\author{
Bilgihan KALKAN *
}

\section{Özet}

Prof. Dr. Ahmed Yüksel Özemre(1935-2008), Türkiye'nin ilk atom mühendisi olmasının yanı sıra Türkiye Atom Enerjisi (TAE) Kurumundaki görevi dolayısı ile ülkemizin tanınmış ilim adamlarındandır. Bu makalede Prof. Dr. Ahmed Yüksel Özemre'nin daha az bilinen ve çocukluk çağlarında tasavvufî muhitler ile yakın temas halinde bulunması ile başlayan ve zaman içerisinde yalnızca entelektüel bir uğraş olmanın ötesine geçerek, yaşam şekline dönüşen tasavvufî hayatı ve genel hatları ile İslâm tasavvufu hakkındaki görüşleri ele alınmaya çalışılmıştır.

Anahtar kelimeler: Tasavvuf, tarikat, şerîat, Uşşâkîlik, Mürşid-i Kâmil.

\section{Mystical Views of Prof.Dr. Ahmed Yüksel Özemre}

\begin{abstract}
Ahmet Yüksel Özemre (1935-2008), was one of our famous scientists known for his works in Turkey Atomic Agency besides he was the first atomic engineer in Turkey. In this article Prof. Dr. Ahmet Yüksel Ozemre's sufi life, which has began with the relation with sufi surroundings in his childhood by exceeding an intellectual interest level and turning out to be a way of life and his opinions about islamic sufism, will be studied.
\end{abstract}

Key words: Sufism, Tariqa, Sharia, Ushaki Sufi Order, The True Sufi Guide.

Yalova Üniversitesi, İlahiyat Fak., Temel İslam Bilimleri Yüksek Lisans Öğrencisi, bilgihankalkan@hotmail.com 


\section{Giriş}

Prof. Dr. Ahmed Yüksel Özemre, 1935'de Üsküdar'da doğmuş; 1954'de Galatasaray Lisesi'nden, 1957'de İstanbul Üniversitesi Fen Fakültesi Matematik-Fizik Bölümü'nden ve 1958 'de de Fransa Nükleer Bilimler ve Teknoloji Millî Enstitüsü’nden mezun olmuştur. Bu itibarla Türkiye'nin ilk Atom Mühendisi'dir. Çeşitli uluslararası bilim kurumunda Türkiye'yi yıllarca temsil eden ve Türkiye Atom Enerjisi Kurumu'nda bir dönem başkanlık görevinde bulunan Prof. Dr. Ahmet Yüksel Özemre, enerjiden tasavvufa, fizikten müziğe, felsefeden edebiyata kadar ilgilenip üretmediği bir alan kalmayan, çok özel bir insandır. Özemre'nin çeşitli konularda yazdığı ya da çevirisini yaptığ 54 kitabı var. Bunların yanı sıra Özemre, 300 makale, halen üniversitelerde okutulan 12 cildi bulan ders kitabı ve ayrıca kültür içerikli 14 kitabın da yazarıdır. ${ }^{1}$

Özemre'nin, çocukluk yıllarında başlayıp, bir Uşşâî şeyhi ile tanışmasına kadar sürecek olan taşkın bir cezbe hâli, ardından talebe yetiştiren bir mürebbî olmaya kadar uzanan tasavvufî yönü ise sınırlı bir çevre d1şında bir sır iken, O'nun kaleme aldığı Üsküdar'da Bir Attar Dükkanı adlı kitabının ardından adeta bu sır ifşa olmuştur.

Türkiye'nin ilk fizik mühendisi olmanın yanı sıra, kendisini tanıyanların filozof mutasavvif²; gönül ehli bir âlim ve bilge bir zat ${ }^{3}$; bilimi, felsefesini, onun yanı sıra ilmi, irfanı dünya hayatımızda yerli yerine koyabilen bir bilge ${ }^{4}$; keşfedilmesi gereken bir âlem ${ }^{5}$ sözleriyle vasfettikleri Özemre, doğup büyüdüğü muhit itibarı ile Cumhuriyet döneminde yaşayan son Osmanlı ulemasını tanıyıp onların kültür birikimlerine tevarüs edebilen, aynı zamanda Galatasaray Lisesi ve ardından yurt dışında yaptığı lisans ve lisansüstü eğitimi ile Batı medeniyetine de hâkim olan, yakın döneme

1 Geniş bilgi için bkz.http:// ozemre.com/ahmed-yüksel-özemrenin-biyografisi

2 Necmeddin Şahinler(Haz.), Çetrefil Bir Adam: Prof.Dr. Ahmed Yüksel Özemre, Kurtuba Kitap, İstanbul2012, s.16, (Ahmed Güner Sayar'ın kitaba yazdığı Takrîz'den)

3 Abdullah Yıldız, “Bilge Bir Üsküdarlı: Ahmed Yüksel Özemre” Umran, İstanbul 2003,S:101, s 95,

4 Prof. Dr. Mim Kemal Öke, "Gel de Çık İşin İçinden!...” (Haz. Necmeddin Şahinler), Çetrefil Bir Adam: Ahmed Yüksel Özemre, s.221.

5 Beşir Ayvazoğlu, “ Özemre Hoca Kendi Cenazesini Nasıl Seyretti?”, Zaman Gazetesi, 03.07. 2008, s.7.

YIL: 5 SAYI: 9 
damgasını vuran bir mütefekkir olması hasebiyle çok farklı yönleri bulunan bir mütefekkirdir. Özemre'nin tasavvufî konulardaki görüşlerini ihtiva eden eserler mevcut olmakla birlikte O'nun bu yönü akademik bir çalışmaya konu olmamıştır. Bu eksiklikten hareketle makalemizin konusunu Özemre'nin tasavvufî yönü ve O`nun bu husustaki görüşleri teşkil edecektir.

\section{Prof.Dr. Ahmet Yüksel Özemre'nin Tasavvufî Hayatı}

Prof. Dr. Ahmed Yüksel Özemre'nin dînî yaşantısına yön veren, daha sonraları ise O'nun tasavvufî hayata yönelmesindeki ilk ve en önemli faktör başta babası olmak üzere ailesi ve yaşadığı muhitteki atmosferdir denilebilir. Onun ilk dînî eğitimini, babası ve onun samimi dostu Saim Düzgünman'dan dinlediği menkıbeler oluşturacaktır. Bu iki dost birbirlerine yaptıkları ev ziyaretlerinde Hz. Peygamber'in ve Ashâb-1 Kirâmın hayatları ile ilgili pek çok ahlâki erdemi içeren menkıbeler anlatırlarken, Özemre bu menkıbeleri nasıl ilgi ve merak ile dinlediğini ve kendisini, hissettirmeden, sağduyulu bir mürebbi ustalığıyla eğittiklerini ve bu sayede küçük yaşlarda Hz. Peygamber ve onun arkadaşlarına karşı muhabbetin kendisinde yerleştiğini anlatır. ${ }^{6}$

Özemre, şeriatın temel kaideleri yanında, Peygamber ve Allah sevgisinin ön plana çıkartıldığı, sözün daima Hz. Peygamber'in ve onun ashabının imanlarına, doğruluklarına, adaletlerine, sadakatlerine, sehâvetlerine, sabırlarına, tahammüllerine, cesaretlerine ve şecaatlerine getirildiği maneviyatını kuvvetlendiren bu menkıbelerin kendisi üzerindeki tesirlerinden şöyle bahsedecektir: "Bunlar daha o günlerden itibaren hayalimdeki "İnsan" idealinin (insan-1 kâmil'in) nasıl olması gerektiğini bana idrak ettirdiydi." "7 Nitekim insan-1 kâmil'in vasıfları meselesinin Özemre'nin üzerinde en fazla durduğu tasavvufî bahislerden biri olduğu gözükmektedir.

Ancak tasavvufî menkıbeleri de çok sevip anlatmalarına karşılık ne babasının, ne de Saim Efendi'nin tasavvufî yönleri ve bu husus da manevi

6 Ahmed Yüksel Özemre, Üsküdar'da Bir Attar Dükkanı, Kubbealtı Yay., İstanbul 20014, s.41.

7 http ://ozemre.com/sayin-ebubekir-sifile-açik-mektup 
bir tecrübeleri yoktur. ${ }^{8}$ Özemre'nin evliyâullahta ortaya çıkan hâl ve tecellilerin etkisinde kalıp bu kişiler ile ilgili soruların kafasını kurcalamaya başlaması, sonradan Eşref Ede (1876-19549)'nin manevi eğitiminde olduğunu öğreneceği, meşhur ebru ustası Mustafa Düzgünman'la (öl.1990) sohbetlerine dayanır. Bu sohbetler sırasında henüz küçük bir çocuk olan Özemre, Mustafa Düzgünman'dan öğrendiklerini dinlerken farkında olmadan onun manevi cezbesinden de etkilenmeye başlar. Ardından kendisi de velilerin halleri, hayat ve düşüncelerine dair pek çok kitabı okumaya başlar. Özemre, Nuriye Akman'a verdiği röportajda da, küçüklügünden beri tasavvuf ve özellikle İbn-i Arabî'nin vahdet-i vücut öğretisini idrak etme hususunda şevki ve heyecanı olduğunu, bunda da okuduklarının ve bulunduğu muhitlerin tesirinin büyük olduğunu anlatacaktır. ${ }^{9}$ Özemre'nin bu süreçte farkına vardığı en önemli şeyse bu kitapları okuyarak manevi bir olgunluğa erişilemeyeceği ve ancak kâmil bir mürşidin insanın elinden tutarak ilerlenebileceğidir. ${ }^{10}$ Özemre zihnini bir sürü sorunun kemirdiği o yıllarda Allah'a karşısına derdine derman olacak bir mürşid-i kâmil çıkarması için niyâz ettiğini anlatır. ${ }^{11}$

Özemre'yi bu yönden en çok etkileyen mekân ise küçük yaşlardan itibaren devam ettiği Saim Düzgünman ve oğullarının işlettiği Üsküdar'daki attar dükkanı ${ }^{12}$ olacaktır. Özemre bir tasavvuf akademisi demek daha doğru olur diye tarif ettiği ${ }^{13}$ bu attar dükkanı sayesinde "her biri o devrin kültürünün mücessem birer aynası idi" ${ }^{14}$ sözleriyle yâd ettiği çok say1da sırlı şahsiyetle tanışma ve onların sohbetlerini dinleme imkânı bulur. ${ }^{15}$ Onun, attar dükkânında, tanışma firsatı bulduğu kişiler ve mekânın atmosferi kendisinde tasavvufa karşı merakının uyanmasına sebep olurken, aynı

8 Özemre, Üsküdar'da Bir Attar Dükkanı, s.45.

9 Röp.Nuriye Akman, “Ahmed Yüksel Özemre - Tasavvuf ile Taoizmin Anahtarı Bir”(Sabah gazetesi 8.10.2001 tarihli nüshası)

10 Özemre, Üsküdar'da Bir Attar Dükkanı, s.55.

11 Özemre, Üsküdar'da Bir Attar Dükkanı, s.56.

12 Söz konusu attar dükkânı hakkında geniş bilgi için bkz. Özemre, Üsküdar'da Bir Attar Dükkant.

13 Ahmet Yüksel Özemre-Necmeddin Şahinler, Kâmil Mürşidlerin Mirası, İnsan Yay., İstanbul 2011, s.19.

14 Özemre, Üsküdar'da Bir Attar Dükkanı, s.73.

15 Söz konusu attar dükkanının müdavimleri hakkında geniş bilgi için bkz. Özemre, Üsküdar'da Bir Attar Dükkanı, , s.23-25.

YIL: 5 SAYI: 9 
zaman da bu dükkan mânevî eğitimi için de adeta bir okul olmuştur. ${ }^{16}$ $\mathrm{Bu}$ attar dükkanı için Özemre, nice sohbetlerin, nice himmetlerin, nice hayırların, nice tefekküre şayan himmetlerin, nice füyûzatın, nice manevî tohumların ve irşatların sebebi ve mihferi olmuştur diye bahsedecektir. ${ }^{17}$

Özemre'nin üzerinde etkisi çok fazla birkaç sırlı şahsiyet vardır. Bunlardan biri, yukarıda adı geçen Eşref Ede' dir. ${ }^{18}$ Eşref Ede, zamanın "Melâmî Kutbu" olarak tanınan Seyyid Abdülkâdir Belhî’nin (1839-1923) ve bir diğer önemli mutasavvıf olan Mehmed Sâbit Efendi’nin (ö. 1920) sohbetlerinde yetişmiş ve onların nezdinde kadri pek yüksek bir zattır. Hatta Özemre, Eyüp'deki dergâhından nerede ise hiç çıkmayan Abdülkâdir Belhî'nin Eşref Ede'nin ricasını kıramayıp Üsküdar'daki bir dergâha gelişinden yola çıkarak bu saygının ancak bir mürşide gösterilebileceği, belki de Ede'nin Belhî'nin halifesi ve O'ndan sonraki Melâmî Kutbu olabileceği sonucuna varır. ${ }^{19}$

Özemre'nin buluğ çağlarında, krize dönüşen bu arayışının farkına varan, çok az konuşan bu sırlı Hamzavî-Melâmî dervişi, nüfuz edici bakışları ile Özemre'nin ifadeleriyle, onu sürekli kontrol altında tutarak hiç fark ettirmeden yönlendirir. ${ }^{20}$ Özemre karşılaşmalarında bakışlarını hep üzerinde hissettiği bu zatın nufûz edici ve sessiz bakışlarının kendisinde ne gibi değişikliklere yol açtığını ancak kırklı yaşlarda idrak edebilecektir. ${ }^{21}$ Özemre'nin çocukluğunda ona irfânî kemâlinin kapısını ilk aralayan kişi olan Eşref Ede'nin, onun tasavvufî düşüncelerine ve yaşantısına adeta damgasını vuran Hamzavî-Melâmî meşrebinin kaynağında bulunan kişi olduğu da söylenebilir.

İlkokulu bitirdikten sonra Galatasaray Lisesi'ne verilen Özemre, bu dönemde kendini spora verir ve profesyonel bir sporcu olarak ciddi başarılar elde eder. Bu delicesine spor yapmaya olan düşkünlüğünün sebebi hakkında ise şöyle diyecektir:

16 Ahmed Yüksel Özemre, Geçmiş Zaman Olur ki, Kubbealtı yay., İstanbul 2012, s.35.

17 Özemre, Üsküdar'da bir Attar Dükkanı, s.24-25.

18 Eşref Ede hakkında daha geniş bigi için bkz. Ahmed Yüksel Özemre, Üsküdar'ın Üç Sirlısı, Kubbealtı Yay. İstanbul 2009, s11-61; Üsküdar'da Bir Attar Dükkanı, s.57-64.

19 Özemre, Üsküdar'ın Üç Sirlısı, 18-.20

20 Özemre-Şahinler, Kâmil Mürşidlerin Mirası, s. 307.

21 Özemre, Üsküdar'in Ü̧̧ Sirlısı, s.8,13. 


\section{$254 \cdot$ YALOVA SOSYAL BILIMLER DERGISI}

“Eşref Efendi Amca'nın nâfiz bakışları ile Mustafa Ağabey'in sohbetlerinin derûnumda uyandırmış olduğu ateşin sebep olduğu cezbemi küllendirmek ve içimdeki kasırgaları gözlerden uzak tutabilmek için delicesine spor yapmaya başlamıştım." 22

İçindeki ateşi bu şekilde de söndüremeyen Özemre, Galatasaray Lisesi'nin 9. sınıfinda iken gittikçe artan cezbesini kontrol altında tutabilmek ve hazmedebilmek için dini bayramlar dışında, senenin her günü oruç tutmaya başlar. ${ }^{23}$ Liseden mezun olduğu yıl (1954), bir yandan orucuna devam ederken, bir yandan da içindeki mistik arayışın bir devamı olarak hummalı bir şekilde matematik ve fizik çalışan Özemre'nin içindeki firtınalar, amcasının delaleti ile bağlandığı Halvetî-Uşşakî şeyhi tarafından dindirilecek ve üç yıldır devam ettiği mutad oruç da yine şeyhinin işareti ile Davut orucuna, ${ }^{24}$ ilk evliliğini yaptıktan sonra ise sadece Ramazan orucuna dönüştürülecektir. Kendisinin, 4 Temmuz 1959'da vefat ettiğini söylediği bu zatın üzerindeki etkisi hakkında Özemre "benim kontrol edemediğim mistik heyecanımı kontrol altına aldı" diye bahsetmektedir. ${ }^{25} \mathrm{Bu}$ zatın 1959 yılında vefat etmesinin ardından, bir yıl kadar muallakta kalan ve o dönemde cezbesinde artma olduğunu söyleyen Özemre, daha sonra onun yerine geçen zata gider ve ona 35 yil hizmet eder. ${ }^{26}$

Özemre kendisinden feyz aldığı "sırlı zatlar" olarak adlandırdığg bazı kişilerden bahsederken iki mürşidinin de isimlerinden hiç bir yerde bahsetmez. Özemre bunun nedenini bir röportajında şöyle izah eder:

"Her ikisi de son derece surlı zatlardı. Herhangi bir yerde isimlerini bulamazsınız. İsimlerini vermekten imtinâ eden kimselerdi. İsimlerini soranlara "Uşşâkî fukarası dersiniz yeter" derlerdi Bir tanesi emekli topçu albaydı. Diğeri ise serbest meslek erbâbı idi." 27

22 Özemre, Üsküdar'da Bir Attar Dükkanı,s.83.

23 Özemre, Galatasarayı Mekteb-i Sultânî sinde Sekiz Yılım, Kubbealtı Yay., İstanbul 201,s.137138.

24 Davîd Orucu: Bir gün oruç tutup bir gün tutmamak şeklinde îfa edilen nafile oruç.

25 Özemre-Şahinler, Kâmil Mürşidlerin Mirası, s.21.

26 Röp. isz., "Prof. Dr. Ahmet Yüksel Özemre ile Geçmişten Günümüze Bir Hasret Sohbeti...", Altınoluk Dergisi, Ocak 1999, S:155, s.11.

27 A.röp., ss.11.

YIL: 5 SAYI: 9 
Özemre, 1954 yılının Aralık ayında karşılaşıtı̆ı bu sırı mürşidi şöyle tasvir eder:

"Orta boylu, beyaz tenli, saçları tam ortadan iki yana doğru ayrılmış, fevkalade nâfiz nazarlı, mukavves kaşlı, insana inşirah bahşeden nûrânî veçhini azametli bir şekilde çevreleyen bembeyaz sakallı ve harikulade biçimde ellere malik bir zattı" ${ }^{28}$

Özemre, mürşidinin mânevî kuvveti hakkında ilk karşılaşmalarında yaşadığı bir olayı da şöyle nakleder:

“...nazarlarını gözlerime tevcih ederek. "Evlâdım, bundan sonra fakiri Hz. Peygamber' in vârisi bileceksin" buyurdu ve o andan itibaren olanlar oldu. Sirrım bu ulu zattan taşan feyz ile önce baştan sona yıkandı ve sonra da tahammülü nispetinde doldu." ${ }^{29}$

Bu sırlı Uşşâkî şeyhinin ilmî vukûfiyetine gelince Özemre, kendisini büyük bir acz içinde bırakan bir Kadr Sûresi tefsirinden bahseder. Söz konusu surenin tefsiri ve te'villeri yaklaşık bir buçuk saat sürmüş ve bu esnada Özemre ikinci tefsirden sonraki bölümü hiçbir şey anlamadan edeben dinleyebilmiştir. O bu olaydan sonra kesbî (çalışarak kazanılan) ilim ile vehbî (Allah tarafından lütfedilen) ilim arasındaki muazzam farkı idrak ettiğini anlatmaktadır. ${ }^{30}$ Özemre'nin bu sözleri karşısında mürşidinin hem ledünnî ilimde, hem de şer'î ilimler noktasında kemâl sahibi bir zat olduğu söylenebilir.

Özemre zaman zaman hâtırâtında anlattığı kişilerin dili ile de mürşidinin çok özel ve kâmil bir zat olduğuna dair işaretler verir. Örneğin Üsküdar'daki attar dükkânının sahiplerinden olan Mustafa Düzgünman'ın Ede'den feyz aldıktan sonra karşılaş̧ığı başka mürşitlere kuşku ile baktığını anlatıp kendi mürşidi ile karş̧laşmalarında yaşanan bir hâdise sebebi ile "mübareğin ona izhar ettiği bir cilve yüzünden Mustafa Düzgünman, Efendi gerçekten de büyük bir zat imiş diye kanaatini izhar ettiydi" ${ }^{31}$ sözlerine yer vererek mürşidinin kemal sahibi bir zat olduğunu onun ağzından teyit eder. ${ }^{32}$

28 Özemre, Üsküdar'da Bir Attar Dükkanı, s.86.

29 Özemre, Üsküdar'da Bir Attar Dükkanı, s.86.

30 Özemre, Üsküdar'da Bir Attar Dükkanı, s.93.

31 Özemre, Üsküdar'in Üç Sirlısı, s.53-54.

32 Özemre'nin mürşidinin fotoğrafi için bkz. EK.1.

YIL: 5 SAYI: 9 
Ahmed Yüksel Özemre'nin tasavvufî eğitiminde önemli olan bir diğer şahsiyet de mürşidinin desturu ile yirmi yıl boyunca onun sohbet şeyhliğini yapacak olan Halvetî-Melâmî meşrepli bankacı Turgut Çulpan (19101990) olacaktır. Özemre'nin Çulpan hakkında verdiği bilgilerden onun, üveysî meşrep ${ }^{33}$ olarak manevi eğitimini Ümmî Sinan'dan itmam etmiş olduğunu ve sonra da bu ahvalin sebep olduğu manevi cezbeyi Ümmî Sinan dergâhının son postnişini Nasûhi Kargı'nın sohbet şeyhliği sayesinde yatıştırabildiğini, "hakiki teslimiyet libâsı ile kendisini beşerin basarından setretmiş" birisi olduğunu öğrenmekteyiz. ${ }^{34}$ Özemre, Çulpan'ın tarikat teşrifatı hakkındaki engin bilgisinden, hikmetinden, celalli-cezbeli ama Rahmânî bakış açısından çok istifade etmiş olduğunu belirtir. ${ }^{35}$

Tasavvufî yönü bu makalemize konu olan Prof. Dr. Ahmed Yüksel Özemre, hangi yönleri ile temayüz etmiş bir sûfî idi? O'nun tasavvufî hayatını belirleyen düsturlar nelerdi? Bu sorulara cevap olarak kendisinin mânevî eğitiminde etkili olan kişilerin şahsiyet özelliklerini tevarüs ettiği, dolayısı ile yukarıdaki sorunun cevabının bu sırlı şahsiyetleri anlattığı satırlarda bulunduğu söylenebilir. Sırladığı Rahmânî emaneti yalnızca ehline tevdî ettiğini söylediği Eşref Ede'nin ve "kendisini ve sahip olduğu ilâhî emaneti özenle sırlayan, Ehl-i Beyti Rasulullah aşkı ile dolu, şeriata sıkı sıkıya bağlı bir ehl-i tarîk idi."36 sözleriyle vasfettiği Turgut Çulpan'ın bahsi geçen vasıflarının ${ }^{37}$ Özemre'nin bu şahsiyetlerden tevarüs ettiği özelliklerin başlıcaları olduğunu söylemek de onun hakkında yanlış bir yargı olmayacaktır.

Nitekim tasavvuf araştırmaları konusunda Türkiye'nin önde gelen isimlerinden biri olan Prof. Dr. Mustafa Kara'nın, Üsküdar>da Bir Attar Dükkanı isimli kitabının yayınlanmasının ardından "Özemre'nin bir âlim olmasının yanı sıra arif olduğu bilinmez. Bu yönü adeta sır idi. Bu kitap ile bazı sırlar keşfedildi." 38 şeklindeki itirafı, Özemre'nin bu sırrı saklama hususundaki başarısını göstermektedir.

33 Üveysî meşrep: Herhangi bir mürşide bey'at etmeksizin seyr-i sülûkunu vefat etmiş bir mürşidden âlem-i mânâda tamamlayarak kemâle ermiş kişi.

34 Özemre, Üsküdar'in Üç Sirlısı, s.81-82.

35 Özemre, Üsküdar'ın Üç Sirlısı, s.86.

36 Özemre, Üsküdar'ın Üç Sirlısı, s.7.

37 Özemre, Üsküdar'ın Üç Sirlısı, s.59.

38 Şahinler, Çetrefil Bir Adam: Ahmed Yüksel Özemre, s.165

YIL: 5 SAYI: 9 
Özemre'yi feyz aldığ 1 kişilerden ayıran yegâne şeyin, onun yazdığ eserlerle "sır" perdesini biraz aralamış olmasıdır denebilir. Özemreınin neredeyse ismiyle özdeşleșen bir eseri olan Üsküdar'da Bir Attâr Dükkânı onun sûfî kişiliğinin inşası hakkında geniş malumat sunmaktadır. Bu eser sayesinde Özemre, bilinen pozitif ilimlerdeki dirayetinin yanında, pek kimse tarafından bilinmeyen irfầnî yönü ile de tanınmaya başlar. Özemre hatıralarını kaleme alarak bu sır perdesini aralamak zorunda kalışının sebebi olarak, bir süre Kubbealtı Akademisi'nin Genel Sekreterliğini yapmış olan Sait Başer'in kendisinden bir konferans vermesini ve konferansta dinleyicilere hayat hikâyesini anlatmasını istediğini anlatır. Bu işe pek tasvipkâr bakmadığını söylediğinde ise Said Başer "Hocam sizi 200-250 genç gelip dinleyecek ve bunların örnek alacakları bir şahsiyeti tanımağa ve onun beşerî sıcaklığını hissetmeğe ihtiyaçları var" der. Özemre, Başer'in sözlerini bir müddet düşünüp bu ricayı kabul eder. ${ }^{39}$

Özemre'nin tasavvufî yönü ile ilgili yazılı kaynaklarda bulabildiğimiz bilgiler, onun ilk gençlik yıllarındaki taşkın cezbe dönemi, bir mürşide intisabı ile devam eden müritlik döneminden ibarettir. Ancak onun çok daha az bilinen bir yönü daha vardır ki, o da yaklaşık otuz yıl kadar sürdürdüğü irşat görevidir.

Özemre'nin isminin yayınlanmasını istemeyen bir müridi ile 01.09.2014 tarihinde yapmış olduğumuz görüşmede, Özemre'nin seksen ile yüz civarında müridi olduğunu, müritlerini seçerken titiz davranıp onların önce sohbetlere devam ile irşada uygun olup olmadıklarının denendiğini, müridânının daha çok entelektüel kişilerden oluştuğunu (nitekim aynı kişi, Özemre ile, kitapları vesilesiyle tanıştığını aktarmıştır), vefatından önce dört halife bıraktığını ve müridânını bu halifeler arasında taksim ettiğini de öğrenmekteyiz.

\section{Prof.Dr. Ahmet Yüksel Özemre'nin Tasavvufî Görüşleri}

Özemre'nin tasavvufî görüşlerine değinmeden önce, onun tasavvuf deyince ne anladığına bakmamız gerekmektedir. Özemre klasik manada bir tasavvuf tanımı yapmaktan ziyade tasavvufun ne olmadığını tespit

39 http://ozemre.com/hatiralarin-işiğinda-mehmet-göze 


\section{$258 \cdot$ YALOVA SOSYAL BILIMLER DERGISI}

etme gayreti içerisindedir. Örneğin söz konusu tespitlerin birinde felsefeyi çok iyi bilen birisi olarak tasavvufun felsefe olmadığının üzerinde ısrarla durur. ${ }^{40}$ Özemre'ye göre tasavvuf deyince iki farklı şey anlaşlır ki; bunlardan birincisi, birtakım sistemler ve kavramlar üzerinde akıl yürütmeden ibaret olan, insanlara zevk de veren bir alandır. Söz konusu faaliyet (uygulamasız tasavvuf) aslında tasavvuf olmaktan çok bir "Tasavvuf Felsefesi"dir. Felsefe olarak kaldıkça söz, münakaşa ve dava yüklüdür. Hâlbuki tasavvuf yolunda kişiler ne kadar manen ilerlerse o ölçüde münakaşa ve cidalden kaçınırlar. Ona göre insan-1 kâmilde bulunması gereken esas vasıf davasızlıktır/iddiasızlıktır.

Özemre tasavvufun tanımını yapmanın zorluğundan bahisle tasavvufu tanımaya çalışmanın en isabetli yolunun hâsıl ettiği etkilerden hareket etmek olduğunu belirterek şöyle der: "Tasavvuf, İslâm Âleminde tekke ve zâviyelerde müesseseleşmiş, gelişmiş ve milli kültürümüzün hiçbir kuvvetinin ortadan kaldıramayacağı bir parçası hâline gelmiş bir düşünce hareketidir." ${ }^{\not 1}$

Tasavvuf dendiğinde kastedilen bir diğer mana da laf kalıplarından vazgeçip, onları hâl edinmek, kişide "ilm-i ledün" teessüs etmesi ve bu ilimle Allah'ın isim, sıfat ve ef'ali hakkında derin bir idrak seviyesine ulaşabilmek ${ }^{42}$ işi teoriden insanın âleme Rahmânî bir bakışla bakmasını sağlayan bir hayat tarzına dönüştürebilmektir. ${ }^{43}$ Esas olan da bu hâli giyinebilmektir.

Özemre, aklın tasavvufî hayat açısından önemi hakkında ise Prof. Dr. Mehmet Can〉a yazdığı bir mektupta şunları söylemektedir:

“Işste, muhterem kardeşim, bendeniz de; yalnızca Kur' an ve peygambere ittibâ ve kezâ başka herhangi bir kimseyi körü körüne taklit etmek yerine (yani aklını hadım edip de onu taklit çengeline asmak yerine) aklı kullanmak farzına riayet edenlerdenim. ${ }^{" 44}$

40 Özemre-Şahinler, Kâmil Mürşidlerin Mirası, s.63-64.

41 Özemre, Şahinler, Kâmil Mürşidlerin Mirası, s.220.

42 Özemre, Şahinler, Kâmil Mürşidlerin Mirası, s.36.

43 Özemre, Şahinler, Kâmil Mürşidlerin Mirası, s.212-213.

44 http://www.uskudarim.org

YIL: 5 SAYI: 9 
Özemre'ye göre, tasavvufun insanların İslâm ile şereflenmesinde yadsınamaz bir payı olması da tesadüf değildir. Çünkü fikıh kelâm gibi normatif ilimlerin ezberciliği ön plana çıkartan soğuk yüzlerinin yanında, tasavvufun peygamber sevgisini öne çıkartan yanı insanlar üzerinde etkili olmaktadır. İslâm tasavvufu bu yönü ile şer'î hükümleri ikinci plana atıyor da değildir. Tam tersine, insanda bir kere Allah ve Resul sevgisi teessüs ederse şeriatın normatif yönü kendiliğinden ve muhabbetle uygulanmaya başlar. ${ }^{45}$

Özemre'ye göre tasavvufun tanımını yapmak zor olduğu gibi, tasavvufî düşünceyi tam olarak idrak edebilmek de kolay değildir. Ona göre yüksek bir idrak, fehâmet, temyiz, ilim, edeb, iz'an ve irfan sahibi olmayanların tasavvufun evrensel boyutunu idrak etmeleri, anlamaları ve sevmeleri ise muhaldir. ${ }^{46}$ Özemre tasavvuf aleyhinde konuşmanın ve mutasavvıfları fütursuzca eleştirmenin bir fazilet olarak görüldüğü kimi mahfilleri nifak ç1karmaya çalışmakla suçlarken, söz konusu çaba içerisinde bulunan kişileri de "ham ervahlar" ${ }^{477}$ olarak nitelemekte de bir beis görmez.

Bunlar yanında Özemre'nin, tasavvuf konusundaki içeriden eleştirel yaklaşımları da dikkate değerdir. O tasavvufun ilk dönemlerdeki sâfiyane yapısının tarikatlaşma ile birlikte nasıl bozulduğu, günümüz tasavvufunun sorunları, sahte şeyhlerin yol açtığı yıkımlar vb konularda da görüş ve eleştirilerini bildirmek sureti ile bir anlamda tasavvufi hayatın ve kurumların özeleştirisini yapmakta ve tasavvufî hayatın içinden biri olmasına rağmen bizlere tasavvuf hususunda objektif bir bakış açısı sunmaktadır.

İslâm Tasavvufunun kâl değil hâl ilmi olduğunun altını sık sık çizen Özemre, tasavvufun teorik-felsefî yönüyle uğraşmanın da kişilere bir takım kazanımlar sağlayacağını kabul eder. Ona göre teorik açıdan İslâm tasavvufundan, kişiye en azından avamın idrak ettiği fizikî âlemi kucaklayan, zâhirî âlemden çok daha zengin olan ve şeriatı özel bir hâl olarak kabul eden, bu yönü ile insanı da zenginleştiren, kemalini arttıran bir "âlem telakkisi" kazandırması beklenebilir. ${ }^{48}$

45 Özemre-Şahinler, Kâmil Mürşidlerin Mirası, s.226.

46 Özemre-Şahinler, Kâmil Mürşidlerin Mirası, s.227,

47 Özemre-Şahinler, Kâmil Mürşidlerin Mirası, ,s.227.

48 Özemre-Şahinler, Kâmil Mürşidlerin Mirası, s.214; 224.

YIL: 5 SAYI: 9 
Özemre söz konusu âlem telakkisi ile farklı asırlar, farklı medeniyet ve dinlerde görülen benzer anlayışlara bakarak bunlar ile İslam Tasavvufu arasında bir sebep-sonuç ilişkisi kurmaya çalışanlara katılmadığını belirtir. Ona göre böyle bir ilişki imkânsızdır. Çünkü İslâm tasavvufunun temelinde bulunan yegâne kaynağın Kur'an olduğu şüphe götürmezdir. ${ }^{49}$

\subsection{Akıl, Hikmet ve İlim}

Bir fizik profesörü ve aynı zamanda bir sûfi olan Özemre'nin birbirine zıtmış gibi görünen bu iki veçheyi kendinde cem etmiş nadir kişilerden biri olması sebebi ile akla bakış tarzı, konumuz açısından da büyük bir öneme haizdir. Özemre'nin "iman ile ikiz kardeş” olarak nitelediği akıl, her şeyden önce salt hayır veya şer değil, tersine hayra da, şerre de kullanılabilen, Kur'an ve sünnet ile sınırlarının çizilmesi gereken ve dirayetle kullanılabilmesi için her zaman Allah'a iltica edilip dua edilmesi gereken bir imkândır. ${ }^{50}$

Sûfiler faaliyet ve yetki alanı duyular âleminden ibaret olan insan aklının (akl-1 meâş, akl-1 tecrübî, akl-1 cüz'î) değerini her vesile ile ifade etmekle birlikte ebedî, ezelî ve yüce hakikatler söz konusu olduğunda, bu alanda metafizik aklın (akl-1 meâd) söz sahibi olduğunu belirtmişlerdir. ${ }^{51}$ Nitekim insan-1 kâmil seviyesine yükselememiş sıradan kişilerin sahip oldukları akl-1 meâş'1, nefse ait, dolayısı ile insanı hatalara sürükleyen bir akıl olarak tarif eden Özemre'ye göre, akl-1 meâş ancak Kur'an ve sahih sünnete uymak sureti ile dize getirilirse ahlak, vicdan ve adalet yönünden sapmaz. Aksini umanlar ise aldanırlar. ${ }^{52}$

Özemre, kâmil insanları diğerlerinden ayırt eden şeyin zâhirî âlemin arkasındaki ilâhî hakikatlerin idrak edilmesini mümkün kılan "akl-ı meâd" olduğunu söyler. Herkeste bulunmayan, ancak eğitim ile kazanılabilen bu akıl kişiye ledün ilminin kapılarını da açar ki, bu ilme sahip olanlar, eşyanın neyi remz ettiğini ve bunun Allah Teâlâ'nın hangi isim ve sıfatının

49 Özemre-Şahinler, Kâmil Mürşidlerin Mirası, s.223.

50 Özemre-Şahinler, Kâmil Mürşidlerin Mirası, s. 28-29.

51 Süleyman Uludağ, “Ak1l (Tasavvuf)”, DİA, İstanbul 1989, C.II ,s.247

52 http://ozemre.com/aklın-yolu-ilimdir-akıl-vahiy-ilişkisi-stv-1999

YIL: 5 SAYI: 9 
eseri olduğunu vasıtasız idrak edebilme yetisi kazanırlar. ${ }^{53} \mathrm{Bu}$ akl-1 meâş sahiplerinin kavrayabileceği bir ilim değildir. ${ }^{54}$

Özemre'ye göre, akl-1 meâş ne kadar üstün olsa da sadece şehadet âleminde işlevi vardır. Gayb âlemine ise bu akılla geçilmez. Bunun için ise kişiye Allah'ın lutfu ile hikmet lütfedilmiş olmalıdır. Akl-ı meaş kesbî olmasına karşılık, akl-1 meâd vehbîdir. ${ }^{55}$

Özemre’ye göre bu iki aklın mahsulü olan iki bilgi türü arasındaki en önemli fark, birincisinin doğrudan doğruya insanın nefsinden kaynaklanıyor olmasına karşılık, diğerinin nefse karşı savaş açıp, nefsini öldüren (ölmeden önce ölen) kişiye verilen bir bilgi olmasıdır. Dolayısı ile birincisi vehme dayalı bir bilgidir. Cenâb-1 Hakk ile kulu ayıran vehim perdesi ortadan kalkınca vehim ve şüpheden uzak, kesin bilgiye ulaşılır. ${ }^{56}$

Söz konusu iki aklın sonucu olan gaybî bilgi ile şehâdet âlemine ait bilgi mahiyet bakımından da birbirinden farklıdırlar. Çünkü gayb âleminin bilgisi sübjektif bir bilgidir. Gayb âlemini aynı anda müşahede eden iki kişinin tecrübesi de bir olmaz. ${ }^{57}$

Özemre`ye göre gayb âlemine ait olan (ledünnî) bilgi ancak fitraten üstün yeteneklere sahip, seçilmiş küçük bir zümreye has, kâmil bir âlimin eğitimi ile farklı bir olgunluk kazanmış kişilere özeldir ve onları hâl sahibi kılmaya yöneliktir. O'na göre her peygamber bahsi geçen özellikleri taşıyan bir zümreyi ayrı bir eğitim ve öğretime tabi tutmuş ve bu özel bilgilerin avama sızmaması için takiyye uygulamak zorunda kalmıştır. Buna rağmen hikmet kırıntılarının ehli olmayan kişilere sızmasına mâni olunamamış ve bu bilgiler avamın arasında nifaka sebep olmuştur. Özemre'ye göre bu durum, dindeki uygulamaların zamanla özünden uzaklaşması ve bazı itikâdî fırkaların ortaya çıkmasına sebep olacak kötü sonuçlar doğurmuştur. $^{58}$

53 Özemre-Şahinler, Kâmil Mürşidlerin Mirası,s.144.

54 Ahmed Yüksel Özemre, Vahye Göre Akıl- İslâm'da Aklın Önemi ve Sinırı, Şule Yay. İstanbul 2006, s. 458.

55 Özemre-Şahinler, Kâmil Mürşidlerin Mirası, s.112.

56 Özemre, Vahye Göre Akll- İslâm'da Aklın Önemi ve Sinırı, s. 458.

57 Röp. Ercan Alkan, Ahmed Yüksel Özemre- "Akıl Vahşi Bir Küheylana Benzer”, Keşkül Dergisi, 2005, S:4, s.61.

58 Özemre-Şahinler, Kâmil Mürşidlerin Mirası, s.64 
Her ne kadar ilm-i ledüne sahip olan kişiler sıradan insanların hayal bile edemeyeceği bir ilmî seviyeye yükselmiş olsalar da Özemre, Allah'ın ilmi ile kulun ilminin hiç bir zaman aynı seviyede olmayacağının da altını çizer. O şöyle der:" Allah Teâlâ ilminin son kertesini kimseye vermez. Evliyasına dâhi vermez." 59

\subsection{Tasavvuf Ve Tarikatlar}

Özemre’ye göre tasavvuf yalnızca İslâm'a has bir vâkıa değildir. İslâm tasavvufununkine benzer bir âlem telâkkisi tarih boyunca farklı zamanlarda, farklı kılıklarda, farklı terminolojilerle zuhur etmiştir. Bu farklı zuhurların birbirlerine bir sebep-sonuç ilişkisi içinde bağımlı oldukları çoğu kere iddia edilmişse de bunun imkânsızlığı pek çok kere ayrıntılı incelemelerle ortaya konulmuştur. Çünkü İslâm tasavvufunun temelinde Kur'ân bulunmaktadır. ${ }^{60}$

Tasavvufta talibin asıl hedefi Cenâb-1 Hak'tır. Ancak burada hangi yol kişiyi bu hedefe götürür sorusu önem kazanmaktadır. Sözlükte yol anlamına gelen "tarik" kelimesinin çoğulu olan tarikatın tasavvuf kitaplarında Allah Teâlâ'ya giden yolların "yıldızlar" adedince ve ya "insanların nefisleri adedince" vb. şekillerdeki yer alan tariflerinde de bu durum açıkça ortaya konmaktadır. ${ }^{61}$

Özemre`ye göre de kişiyi Allah'a götüren ve kemâle ulaştıran pek çok yol ve yordam vardır. Mühim olan ise insanın hayatı ve yetenekleri ile mütenâsip bir yol bulabilmesidir. ${ }^{62}$ Özemre'ye göre tarikatların amacı, tarikata giren kişilere (sâlik), dünyevî idrakten uhrevî idrake giden yolda (seyr-ü sülûk) önlerine çıkan nefs ve vehim engellerini ortadan kaldırmaya yönelik bir yöntem uygulayarak, onları nebevî ahlâk sahibi kılmaktan ibarettir. ${ }^{63}$ Yani tarikat, gayesi yalnızca uhrevî olan bir meşguliyet olup,

59 Özemre-Şahinler, Kâmil Mürşidlerin Mirası, s.74.

60 Toshiko İzutsu, İbn-i Arâbî'nin Fusûs'undaki Anahtar- Kavramlar, (Çev: Ahmed Yüksel Özemre), Kaknüs Yay., İstanbul 1998,s.10-11.

61 Reşat Öngören, “Tarikat”,DİA, C.LX, İstanbul 2011, s.95.

62 Özemre-Şahinler, Kâmil Mürşidlerin Mirası, s.62-63.

63 Özemre, Şahinler, Kâmil Mürşidlerin Mirası, s.214.

YIL: 5 SAYI: 9 
dünyevî gayesi olan her hangi bir işten uzak duran bir kurumdur. ${ }^{64}$ Ona göre tarikatları kötüleyenler, bu amaçtan habersiz kişilerden başkaları değildir.

Ancak zaman içinde dünyevîleşme neticesinde bu hedeften sapıldığ1 görülmektedir. Bu durumun neticesi olarak tarikatların içine bir takım yabancı öğeler de karışmıştır. Kâmil şeyhlerin yönetiminde uhrevî hedeflerinden sapmayan tarikatlar ile bu idealden sapan seküler uygulamaların başka şeyler olduğunu idrak edebilmek için bazı vasıflara haiz olmak gereklidir. ${ }^{65}$

Özemre'ye göre tasavvuf düşüncesi, tekkelerin kurulması, bu müesseselerin ihtiyaçlarını karşılayacak kaynaklara yönelme ve dünyevî güç odaklarının güdümüne girme, tekkeler arasında zaman zaman üstünlük yarışına girilmesi ve "hurde-i tarîk" denilen ritüellerin ön plana çıkması gibi sebepler ile yozlaşmaya başlamıştır. Ayrıca talep vaki olmaksızın insanları tarikatlara davet edilmesi, tarikatların bozulma sebepleri arasında yer almaktadir. ${ }^{66}$

Özemre ye göre tarikatların hemen hepsinin âdab ve erkânı oluşturulurken ilk kurucu pirlerinin görüşlerinden az ya da çok uzaklaşılmış, bulundukları yörelerin âdab ve erkânı tarikat uygulamalarına dâhil olmuştur. Ona göre hemen hemen hiçbir tarikat bu durumdan hâli değilken, söz konusu durumun özellikle ve sadece Bektaşiler için söz konusu imiş gibi algılanmasının sebebiyse, diğer tarikatların Bektaşilik kadar siyasallaşmamasıdır. Dolayısı ile siyasi yanlarının olmaması bu tarikatlarda yaşanan pek çok ilginç ve tuhaf olayın da gizli kalmasının sebebi olmuştur. ${ }^{67}$

\subsection{1. Şeriat/Tarikat}

Özemre, şeriat ile tarikat arasında bulunan ayrımı «genel / özel, mecburî / isteğe bağl1, farzlar ile mükellefiyet / sünnetleri de idame ettirme

64 Özemre, Vahye Göre Akıl- İslâm'da Aklın Önemi ve Sinırı, s.158.

65 Özemre, Vahye Göre Akıl- İslâm'da Aklın Önemi ve Sinırı, s. 159.

66 Özemre- Şahinler, Kâmil Mürşidlerin Mirası, s.206-207.

67 Özemre, Şahinler, Kâmil Mürşidlerin Mirası, s.85. 


\section{$264 \cdot$ YALOVA SOSYAL BILIMLER DERGISI}

ile mükellefiyet» sözcükleri ile tarif eder. ${ }^{68}$ Özemre'ye göre şeriat, Allah Teâlâ'nın rızasını kazanmanın kurallarını oluştururken, tarikat ise, önce nefis ve ruh daha sonra da Allah Teâlâ hakkında şeriatın sağladığından çok daha geniş ve derin bilgi sahibi olmanın ipuçlarını gösteren bir yoldur. ${ }^{69}$ Herkes tarikat ehli olamaz. Biz şeriat ile emrolunmuşuzdur. Hâlbuki tarikata girmek ne farz, ne de sünnettir. ${ }^{70}$

Özemreıye göre tarikatlar sekülerleşmediği sürece temel gayesi beşeri insan kılmak olan müesseselerdir. Tarikat müessesesinin dayandığ 1 iki temel strateji vardır: Nefse karşı cihad ve cehalete karşı cihad. Bu eğitim kişiye ledün ilminin kapılarını açar. Ve Allah'ın huzuruna kabul edilmeye (Miraç) hazır hale getirir. ${ }^{71}$

Yukarıda bahsi geçtiği üzere Özemre ilmi, mü'minlerin geneline has olan ve özel (seçilmiş) kişilere has olan şeklinde bir ayrıma tâbi tutarak, ledünnî ilim sahibi olan kişilerin hakikati vasıtasız görebildiklerini kabul etse de, bu durumun onları şeriatın emirlerini uygulamaktan, farz ibadetleri ifa etmekten müstağni kılmadığının da altını çizer. ${ }^{72}$ Ona göre, şeriatsız ilm-i ledün mümkün değildir. Şeriatsız ilm-i ledünne dalmak isteyen muhakkak küfre veya zındıklığa düşer. ${ }^{73}$

Özemre, şeriata dayanmayan bir tasavvufun bâtıl olduğu hususunun altını çizer ve bu çerçeve içinde tasavvufun ibâhacılık için bahane edilemeyecek bir edeb olduğunu da vurgular. ${ }^{74}$ Ona göre, tarikatta olmak kişiyi İslâm şeriatından müstağni kılmadığı gibi, müride ayrı bir şeriat daha yükler. Özemre bu durumu "Tarikatın da şeriatı vardır" cümlesi ile özetler. Örneğin tarikatta mürşit müridin babası sayıldığı için ihvanından biri ile evlenmesi haramdır. ${ }^{75}$

68 Özemre, Şahinler, Kâmil Mürşidlerin Mirası, s.82-83.

69 Özemre, Vahye Göre Akıl- Íslâm'da Aklın Önemi Sinırl, s.160-161.

70 Alkan, A.g. röp., Keşkül dergisi, s.64.

71 Özemre, Vahye Göre Akıl- Íslâm'da Aklın Önemi Sinırl, s.540-541.

72 Özemre-Şahinler, Kâmil Mürşidlerin Mirası, s.84.

73 A.g. röp., Altınoluk Dergisi, Sene:1995, Sayı:155, s.11.

74 Özemre, Şahinler, Kâmil Mürşidlerin Mirası, 223.

75 Özemre, Şahinler, Kâmil Mürşidlerin Mirası, s.89.

YIL: 5 SAYI: 9 
Özemre'nin hakikate erişmiş, bâtına da nazar edebilen kişiler olarak tanımladığı bu özel kişiler, sıradan halkın (avam) nifaka düşmemesi için zâhire karşı tutumlarında klişeleşmiş itikadın dışına çıkmamaya da özen gösterirler. Çünkü hakikate ermiş olmak kişiyi itikadî ve şer'î hükümlerden muaf k1lyyor olsa idi öncelikle Hz. Peygamber'in böyle davranmas1 gerekirdi. Bu noktada sûfînin örneği Hz. Peygamber'den başkası değildir. ${ }^{76}$

\subsubsection{Sekülerleşen Tarikat Yapılanmasına Tepki Hareketi: Melâmet}

Prof. Dr. Ahmet Yüksel Özemre'nin hâtırâtında "Eşref Efendi Amca" şeklinde bahsi geçen zatın Hamzavî- Melâmî oluşu ve yine kendisinin sohbet şeyhi olan Turgut Çulpan'ın da Halvetî-Melâmî oluşu, onun tasavvuf anlayışı üzerinde Melâmî neş'enin hâkim olmasında etkili olmuştur. Özemre'nin üzerinde müessir olan bu etki, onun gerek sözlü sohbetlerinde, gerekse yazılarında kendi mensubu olduğu Halvetî-Uşşakî tarîkından çok daha fazla Melâmîlerin tarihi, meşrepleri ve bu yolun faziletleri üzerinde durmasina sebep olmuştur.

Özemre'ye göre Melâmetîlik için yapılabilecek en güzel tanım, Hz. Peygamber'in ahlâkını izhar etmektir. ${ }^{77}$ Ona göre Melâmîler her devirde nefsini zelil kılmış, cemiyet içinde erimiş gibi yaşamış, Hz. Peygamberin tavrına sahip olmuş kişilerdir. ${ }^{78}$

Özemre'ye göre "Melâmîler, bâtında bir iddiası, zâhirinde ise yapmacıklık ve riyakarlık olmayan" kişilerdir. Ona göre bir Melâmî için iddia sahibi olmak düşünülemez. Melâmîler, insanların övme ve yermesine aldırış etmemeyi de bir prensip olarak benimseyen kişiler olduklarından, öyle kutupluk, gavslık gibi unvanlara itibar etmezler. Çünkü böyle unvanlar ancak kişinin nefsini okşar. Hâlbuki Melâmîler Hz. Peygamber'in sık sık söylediği "Ben de sizin gibi bir insanım" sözünü en önemli ilkelerinden biri edinerek nefislerinin hilelerini tespit etme noktasında temyiz

\footnotetext{
76 Özemre-Şahinler, Kâmil Mürşidlerin Mirası, s.214

77 Özemre-Şahinler, Kâmil Mürşidlerin Mirası, s.309.

78 Özemre-Şahinler, Kâmil Mürşidlerin Mirası, s.26.
}

YIL: 5 SAYI: 9 
sahibi olmaya gayret eden kişilerdir. ${ }^{79}$

Özemre, tasavvufî hayatı uygulama açısından başlıca iki tavra ayırır. Bunlardan birincisi "dergâh tavrı" diye adlandırdığı çok ağır bir çile uygulaması ile müridin nefsinin yavaş yavaş eriyip yok olmasını sağlayan bir eğitim metodudur. İkinci metot ise müridin ufacık 1şıksız bir hücreye kapanarak değil cemiyet içinde çile çekerek eğitilmesi şeklindedir ki; bu ikinci tavır Melâmîlerin izlediği tavırdır. ${ }^{80}$

Ona göre başlangıçta ilm-i ledün eğitiminden ibaret olan tasavvuf düşüncesi, tekkelerin kurulması ile birlikte, kaçınılmaz bir biçimde dünyevîleşip yozlaşmış ${ }^{81}$ şatafatlı merasimler ile fuzulî meşguliyet ilm-i ledün tedrîsinin önüne geçmiş ve taklidin hükümranlığı başlamıştır. Özemre'ye göre bu duruma ilk kısmî tepki, Melâmîlerden gelmiş ${ }^{82}$ ve Hamzavî-Melâmî (ya da II. Devre Melâmîliği) geleneğinde doruğa ulaşmıştır. ${ }^{83}$

Özemre'ye göre tasavvuf erbabının dünyevî güç odakları ile fazlaca içli-dışlı olmalarına ve tekke teşrifatına bir reaksiyon olarak ortaya çıan Melâmîler, özellikle de 17. yüzyıldan itibaren tekke hayatını terk ederek cemiyet içine çekilmiş olan Hamzavî-Melâmiler, tasavvufî hayatın, tekkelere bulaşmadan da var olabileceğinin müşahhas örneği olmuşlardır. ${ }^{84}$

Özemre'ye göre diğer tarikatların aksine, kendilerini halktan (avam) ayırdığı için nefsi okşayan tekke hayatını dışlayan Hamzavî Melâmîlerin bu tavrı farklı ve diğerlerinden daha zor, ancak daha etkili bir eğitim metodudur. Örneğin bir nefs eğitim metodu olarak yer alan "halvet" veya "çile", ufacık ve ş̧ıksız bir hücreye kapanıp az yemek ve içmek şeklinde uygulanırken, Hamzavî Melâmîlerde mürit kendi çilesini cemiyetin içerisinde çeker. Özemre'ye göre bu çeşit bir halvet ile nefis eğitimi diğerinden daha da zordur. Sebebine gelince; birinci durum başlangıçta nefse ağır gelmesine rağmen, onuncu günden sonra insana kolay gelir ve

79 Özemre-Şahinler, Kâmil Mürşidlerin Mirası, s.312-313,

80 http://ozemre.com./aklın-yolu-ilimdir-hz-isâ-ve-musîbetler-2-bölüm-stv-1999.

81 Özemre-Şahinler, Kâmil Mürşidlerin Mirası, s.206.

82 http://ozemre.com./aklın-yolu-ilimdir-hz-isâ-ve-musîbetler-2-bölüm-stv-1999.

83 Özemre-Şahinler, Kâmil Mürşidlerin Mirası, s.102.

84 Özemre-Şahinler, Kâmil Mürşidlerin Mirası, s.208-209.

YIL: 5 SAYI: 9 
halvetten çıkan kişinin nefsi "ben ne büyük işler başardım" diyerek bir iddiada bulunurken halkın içinde çekilen çilede nefsin faydalanabileceği bir pay olmadığından bu durum nefse daha zor gelir. İkinci olarak cemiyetin içerisinde çekilen çile ile devamlı surette idrakte olan kişi için bu durum ileriki hayatında çok daha eğitici bir hâle gelir. ${ }^{85}$

Özemre'nin Melâmet tavrını anlatırken sürekli olarak $\mathrm{Hz}$. Peygamber'in davranışlarına dikkat çekmesi ve şeriat vurgusu yapması günümüzde Melâmîler ile ilgili oluşan olumsuz algıyı bir nebze olsun düzeltmeye ve asıl Melâmîliğin ne olduğunu izah etmeye yönelik olduğu söylenebilir. Ona göre zamanla dînî hükümlere uymak istemeyen kişilerin Melâmîlik kisvesine bürünerek bu yolu keyfî uygulamalar ile doldurdukları da göz ardı edilemez.

Özemre söz konusu bozulma ve yoldan sapmalara Üçüncü Devre Melâmîleri (Nûriye Melâmîleri)'nin benimsedikleri usulleri örnek olarak gösterir ve İkinci Devre Melâmîleri (Hamzavî Melâmîler) ile aralarındaki öğreti farkını ortaya koymaya çalışarak Nuriye Melâmilerinin benimsedikleri idealleri tasvip etmediğini açıkça ortaya koyar. ${ }^{86}$

Özemre, 1925 y1lında yürürlüğe giren tekke ve zâviyeler ile türbelerin kapatılmasına dâir kanuna tepki göstermek şöyle dursun, bu durumu söz konusu yozlaşmanın önüne geçen bir gelişme olarak değerlendirir. Bu kanun sayesinde tarikat hayatının folklorik veçhesine son verildiğini, ancak tasavvuf ile samimi olarak ilgilenenlerin bu yoldaki arayışlarının devam ettiğini ve artık kendini gizleyen kâmilleri yine arayıp bulduklarını ifade eder ${ }^{87}$ Özemre'nin tekkelerin kapatılması olayına konunun içinden birisi olarak getirmiş olduğu bu yorum onun tasavvufî görüşlerinin şekillenmesinde Melâmî tavrın ne kadar etkili olduğunu göstermesi bakımından önemlidir.

85 http://ozemre.com./aklın-yolu-ilimdir-hz-isâ-ve-musîbetler-2-bölüm-stv-1999.

86 Özemre'nin Üçüncü Devre Melâmîler hakkında yaptığı izah ve tenkitler hakkında geniş bilgi için bkz. Özemre-Şahinler, Kâmil Mürşidlerin Mirası, s.320-324

87 Özemre, Vahye Göre Akıl- İslâm'da Aklın Önemi ve Sinırı, "VII. Tarikat”, s.159. YIL: 5 SAYI: 9 
$268 \cdot$ YALOVA SOSYAL BILIMLER DERGISI

\subsection{Kâmil İnsan}

Prof. Dr. Ahmet Yüksel Özemre'ye göre bütün cemiyetlerde ve gelmiş geçmiş tüm ideolojilerde insanların kendilerine örnek aldıkları olgun bir şahsiyet, insan-1 kâmil ${ }^{88}$ ideali mutlaka bulunur. İslâmiyet'te de insan-1 kâmil kavramı (bilhassa tasavvufta) merkezî bir rol oynar. Ancak İslâm tasavvufunun ortaya koyduğu olgun insan kavramı ile diğer sistemlerdeki olgun insan kavramı arasında büyük farklar bulunmaktadır. ${ }^{89}$ Öncelikle İslamiyet'in insan-1 kâmil prototipi Hz. Peygamber'dir, insan tekâmülünün en yüksek hedefi de onun ahlakı ile ahlaklanmaktır. ${ }^{90}$ İkinci olarak da İslâmiyet'teki insan-1 kâmil idealine erişmek olağanüstü zordur. Bu bazen bir ömür süren meşakkatli bir eğitimi gerektirir. Bu eğitimi verecek kişinin de bir insan-1 kâmil olmas1 ${ }^{91}$ ve buna ilaveten de bir mürşid-i kâmilden mürebbilik konusunda kendisine halifelik görevi yüklenmiş biri olması şarttır. ${ }^{92}$

Özemre'ye göre, insanı eşref-i mahlûkat yapan özellik, yalnızca insana verilen ilâhî emanet yani Ruhullah'tır. Ancak bunu bil'kuvve olma durumundan bilfiil olma durumuna çıarmak, insan için mestûr kalan bu ilâhî emaneti idrak edebilmek ve kaynağına ulaşabilmek, herkesin harcı değildir. Pek az kişiye nasip olan bu zenginliğe ulaşabilmenin sırrı ölmek (Hakk'ın Zât ummanında ifnâ olmak) ve yeniden dirilmek (yine aynı zâhirî surette ancak Zât'-1 İlâhî'nin her daim zinde idraki ile dünyaya dönmek) tir. Özemre'ye göre insan bu dünyada Zât nurundan ikinci kez doğabilir. Bu doğumun gerçekleşmesi durumunda ise insanda eşya üzerinde İlâhî bir tasarrufta bulunabilme hâlinin ortaya çıkması mümkündür. ${ }^{93}$

Peki, her Müslümanın böyle bir idrak seviyesine ulaşması şart mıdır? Allah her insanda kemâle erebilme potansiyeli yaratmasına rağmen, herkesin kemale ermesini murat etmiş de değildir. Özemre'ye göre tüm

88 İnsan-1 Kâmil terimi hakkında geniş bilgi için bkz. Mehmet S. Aydın, "İnsan-1 Kâmil”, Di், C. XXII, İstanbul 2000, s.330-331.

89 Özemre, Vahye Göre Akıl-İslâm'da Aklın Önemi ve Sinırı, s.243.

90 Özemre-Şahinler, Kâmil Mürşidlerin Mirası, s.78.

91 Özemre, Vahye Göre Akıl-İslâm'da Aklın Önemi ve Sinırı, s.245.

92 Özemre-Şahinler, Kâmil Mürşidlerin Mirası, s.328,

93 Özemre, Şahinler, Kâmil Mürşidlerin Mirası, s.240-241.

YIL: 5 SAYI: 9 
Müslümanların yapmakla sorumlu oldukları asgarî alan “şeriat”tır. Ancak şeriatla yetinmeyen, onun arkasındaki ilâhî hakikatleri de anlamak isteyen bazı özel yetenekli kişiler her zaman var olacaktır. Bu durumdaki kişiler için esas mesele, beşer hâlinden kurtulup kemâle doğru nasıl yol alınabileceğini bildiren bir bilgiye ulaşabilme meselesidir. ${ }^{94}$

\subsubsection{Miraç (Kâmil İnsan Olmanın Şartı )}

İslam Tarihinde Malum Bir Vâkıa Olan Hz. Peygamber'in miracı, Müslümanların geneli tarafından sadece ona has bir durum olarak değerlendirilmekte ve kabul görmekte iken Özemre'ye göre miraç, tasavvufta manevî yükselişini tamamlayan ve kemâle eren her mürit için fil'hakîka yaşanıp tecrübe edilen bir olaydır. Miraç, Allah Teâlâ'nın huzuruna çıkıp velayeti ondan almaktır. ${ }^{95}$ Bir diğer tanıma göre ise miraç, bedenin ölümü vukû bulmadan önce yaratana kavuşmanın idrakinin yaşandığı ve sonucunda vehim ve şüpheden uzak, otantik bir mânevî tecrübenin yaşandığ 1 ve kişiye Allah Teâlâ tarafından özel bir bilginin (yakîn) lütfedildiği manevî bir tecrübedir. Kendisine miraç lütfedilen kişiye "veli" denilir. ${ }^{96}$

Özemre'ye göre Allah, velisi olan kişiye miraçda, yakîn ${ }^{97}$; zâtî ilminden bir ilim; hikmetinden bir hikmet ve akl-1 mead ${ }^{98}$ lütfeder ve Esmâ-i Hüsnâ'sının tecellilerine mazhar kılar. ${ }^{99}$

Özemre, bu durumu ümmetin peygambere her hususta ittibâsının zarûrî bir sonucu olarak görür. ${ }^{100}$ Ancak bu peygamberin miracı ile evliyaullahın miracı tam olarak aynı mahiyettedir anlamına da gelmez. Çünkü

94 http://ozemre.com/hayat1- ibâdet-k1lmak- trt-2006.

95 Özemre-Şahinler, Kâmil Mürşidlerin Mirası, s.91.

96 Özemre, Vahye Göre Akıl- İslâm'da Aklın Önemi ve Sinırı, s.555.

97 Özemre bu bahiste Hicr suresi 99. Ayette geçen "yakîn" terimine pek çok konuşmasında atıfta bulunur ve terimin "ölüm gelmeden” şeklinde yapılan Türkçe tercümelerini doğru bulmaz.

98 Özemre-Şahinler, Kâmil Mürşidlerin Mirası, s.115.

99 Özemre, Vahye Göre Akıl- Íslâm'da Aklın Önemi ve Sinırı, s.168.

100 Özemre'ye göre, peygamberlere bahşedilen lutf-u İlâhî diğer hususlarda da ümmetlerine de şâmildir. Dolayısı ile O'na göre evliyûllah için vahiy de söz konusudur. Şu farkla ki; peygamberlere vâki olan vahiy umumi iken evliyâullaha vaki olan vahiy hususidir. Evliyâullaha gelen şeylere "vahiy" değil "ilham” denir. (Özemre-Şahinler, Kâmil Mürşidlerin Mirası, s.91) 
miracını tamamlayıp da, şuur hâline geri dönen evliyanın peygamberlerden farklı olarak kendisinde zuhur edecek olan cezbe hâlini hazmetmesi için bir mürşide ihtiyacı vardır. Aksi takdirde tıpkı Hallac-1 Mansur'da olduğu gibi kendisinden şeriata aykırı haller zuhur eder. ${ }^{101}$

Cezbesini hazmeden her velinin tavrı ve hususiyetleri de aynı değildir. Özemre bir veliye miraç esnasında ne lütfedildi ise şehâdet âlemine döndüğünde ancak onu izhar edebileceğini belirtir. ${ }^{102}$

Hz. Peygamber'in ümmetine has olan miracın bazı hususiyetleri vardır. Miraç vehbîdir. Ancak miracı gerçekleştirmek için kişinin "sâfiyet" mertebesine yükselmesi gerekir ki, bu da cehd gerektirir. Nefse karşı yapılan cihad ise kesbîdir. ${ }^{103}$ Allah bir kişiye miraç lütfetmemiş ise o ilim bakımından hâlâ cahildir. ${ }^{104}$

Evliyalığın olmazsa olmazı olan miraç, ölmeden önce ölme sırrına mazhar olup, Allah'ın huzuruna yine onun tarafından çıkartılmaktır. Kişi miracını yaşayıp Allah'ın huzuruna çıktıktan sonra ya bu âleme yeniden gönderilir, ya da bedeni burada, ruhu huzur-u ilâhîde kalır. ${ }^{105}$ Özemre'ye göre miracını gerçekleştiren kişi her ne kadar zahir realitesini aşarak bir üst hakikate ulaşmış olsa da zahire karşı tutumunda avam içinde nifaka sebep olmamak için daima temkin ile hareket etmelidir. $\mathrm{O}$ bu konuda en güzel örneğin Hz. Peygamber olduğuna da dikkat çeker. ${ }^{106}$

Miracı hakkı ile ancak yaşayan bilebilir, bu durumu başkasına anlatabilmesi ise mümkün değildir. Durum böyle olduğu halde bu tecrübeyi yaşayanların bir kısmı, yaşadıklarına şu ve ya bu şekilde değinmeden de edememişler ve söz kalıplarına sığmayacak bu tecrübeyi bazı istiareler ile anlatmaya çalışmışlardır. ${ }^{107}$ Miracını gerçekleştirmiş kişi Allah'a arif olmakla birlikte onu zâtı ile idrak edip tanıyamaz. Çünkü Allah'ı idrak aklın işi değildir. ${ }^{108}$

101 Alkan, A.g.röp., Keşkül Dergisi, s. 64.

102 Özemre, Vahye Göre Akıl- İslâm'da Aklın Önemi ve Sinırı, s.556.

103 Özemre, Vahye Göre Akıl- İslâm'da Aklın Önemi ve Sinırı, s.188.

104 Özemre-Şahinler, Kâmil Mürşidlerin Mirası, s.70.

105 Özemre, Vahye Göre Akıl- İslâm'da Aklın Önemi ve Sinırı, s.246.

106 Özemre-Şahinler, Kâmil Mürşidlerin Mirası , s.214.

107 Özemre, Vahye Göre Akıl- İslâm'da Aklın Önemi ve Sinırı, s.556.

108 Özemre-Şahinler, Kâmil Mürşidlerin Mirası, s.175-176.

YIL: 5 SAYI: 9 


\subsubsection{Kâmil Mürşid}

Özemre'ye göre, sâlikin eğitimi meselesi mürşid-i kâmilde dügüumlenir. Her ilmi tahsil için bir hocaya ihtiyaç duyulması nasıl tabii ve zorunlu bir hâl ise, ilm-i ledün denilen bilgi türünü kuşanacak olgunluğa ulaşmak isteyenlerin de kâmil bir yol göstericiye müracaat etmelerinin gerekliliği de aşikârdır. Tasavvufun teorik veçhesinden onun bir «hayat tarzı» olma veçhesine geçmek isteyen kişinin, bir mürşid-i kâmilin ahlâkını kendisine örnek ve rehber olarak alması lâzımdır. Aksi halde bütün çabaların sonucunda ortaya bir insan-1 kâmil değil, yarı derviş çıkar. ${ }^{109}$ Ancak şunu da unutmamak gerekir ki, ilm-i ledün konusunda bir istek ve arzusu olup mürşit arayanların içinden sadece nasibi olanlar kâmil bir mürşit bulabilirler. Yani bu bir nasip meselesidir. ${ }^{110}$

Özemre, insan-1 kâmil yetişmesi için bir mürşid-i kâmilin terbiyesinin gerekliliğine vurgu yaparken, onun insan ile Allah arasında aracı olmaktan uzak olduğunun da altını çizer. Özemre bu konu ile ilgili şunları söyler: «Eğer bir kimse şeyhini Allah ile kendi arasında aracı olarak görüyorsa, o apaçık bir dalalet içindedir. Eğer bu fikri ona kendi şeyhi telkin etti ise, şeyhi de apaçık dalalet içindedir. Bunun şekki, şüphesi yoktur.»» ${ }^{111}$

Özemre'ye göre kerâmet göstermek asla bir mürşid-i kâmil olmak için kıstas değildir. Kâmil mürşitlerin iki tür kerametleri vardır: Birincisi, taliplerin yeteneklerini keşfetmeleri, ikincisi ise, onların pas tutmuş nefislerini altına dönüştürmeleridir. Bundan dolayı mürşid-i kâmiller' in "Kibrit-i Ahmer" ${ }^{112}$ oldukları söylenegelmiştir. ${ }^{113}$ Çünkü velayet mertebesine ermiş kişilerin rahle-i tedrisinden geçen kişilerin nefislerinin kötülükleri birer birer izale olur ve kendileri altın gibi parıldamaya başlar. Özemre’ye göre kendi varlığını Zât nurunda ifnâ eden ve onun nurundan yeniden doğan bir velinin, o makamın sahibi gibi Hayy olacağına ve varlık dağıtacağına da

109 Özemre, Vahye Göre Akll- İslâm'da Aklın Önemi ve Sinırı, s.109.

110 Özemre, Vahye Göre Akıl- İslâm'da Aklın Önemi ve Sinırı, s.202.

111 Özemre-Şahinler, Kâmil Mürşidlerin Mirası, s.84.

112 Kibrit-i Ahmer:( Dokunduğu her şeyi altına dönüştüren bir kimya): Özemre’ye göre Orta Çağ'da batılıların ilm-i simya yolu ile aradıkları ve dokunduğu nesneyi altın yapan Filozof Taşı, mutasavvıfların Kibrit-i Ahmer dedikleri Arapça bir kavramı idrakten yoksun kalan kişilerin elinde anlamını yitirmiş bir kavramdan ibarettir.

113 Özemre, Vahya Göre Akıl- İslâm'da Aklın Önemi ve Sinırı, s.205. 
hiç şüphe yoktur. ${ }^{114}$

Özemre, mürşid-i kâmilin dokunduğunu değiştiren, büyük bir manevi güce sahip olduğunu belirtirken, bir mürşidin kemâlinin ancak Hz. Peygamber'e nisbetle var olan izâfî bir kemâl olduğunu, söz konusu mürşitlerin mânevî makamlarının asla Peygamber'in makamı ile bir veya daha üst bir yerde olmadığının da altını çizer. Ona göre her mürşit, Hz. Peygamber'e hâl, kâl, tavır ve meşrep olarak mümkün mertebe benzemek ile mükelleftir. ${ }^{115}$ Özemre cezbeli, temkîn ve teennîden uzak bir tasavvufî yaşantıyı kemâl ehli kişiler için hoş görmez. Bu tarz taşkınlıkların Hz. Peygamber'in hayatında yeri olmadığı gibi kemâle kavuşmak söz konusu olunca da yeri olmamalıdir. ${ }^{116}$

Özemre, günümüzde televizyonlara çıkan, kendilerine ilim verildiğini, yazdıkları kitapları, kerametlerini ve diğer bazı hususiyetlerini anlatan mutasavvıfları da eleştirir. Çünkü gerçek velinin en önemli hususiyetlerinden biri de sırrını izhardan uzak durmasıdır. ${ }^{117}$

Özemre'nin günümüz tarikatlarında son derece yaygın olan müridmürşid ilişkisine getirdiği bazı eleştiriler de dikkat çekicidir. Ona göre kemâl sahibi mürşitlerin sorumlulukları (ilm-i ledünn eğitimi vermek) son derece mesuliyetli bir iştir. Mürşid-i kâmil, eğitimini üslendiği kişinin her bakımdan vasisidir. Dolayısıyla tâlibin böyle bir eğitime müsait olup olmadığını kontrol etmeden talepleri kabul etmemesi gerekir. ${ }^{118}$ Özemre, günümüzde tarikata giren her müridin eline tutuşturulan fotokopi çektirilmiş kâğıtlar ile ders verilmesine şiddetle karşı çıkar. Çünkü herkes kendi yeteneğine göre yetiştirilmelidir. ${ }^{119}$

Özemre, sayıları binler, on binleri bulan mürşitleri de eleştirerek bu kadar çok ihvanın tam manası ile eğitilmesinin mümkün olamayacağını ifade eder. Ona göre bir mürşide bağlanacak kişilerin sayısı, mürşit çalışmak zorunda ise 〈elli〉yi, çalışması gerekmeyip sohbete müsait ise

114 Özemre-Şahinler, Kâmil Mürşidlerin Mirası , s.242

115 Özemre-Şahinler, Kâmil Mürşidlerin Mirası, s.98.

116 Özemre, Vahye Göre Akıl- İslâm'da Aklın Önemi ve Sinırı, s.202.

117 Özemre-Şahinler, Kâmil Mürşidlerin Mirası, s.86.

118 Alkan, A.g.röp., Keşkül Dergisi, s. 65.

119 Özemre,-Şahinler, Kâmil Mürşidlerin Mirası , s.38.

YIL: 5 SAYI: 9 
〈yüz〉ü geçmemelidir. ${ }^{120}$

Özemre'ye göre, mürşid-i kâmillerin mânevî eğitimde kullandıkları başlica yöntem sohbet ve nazar olup ${ }^{121}$ vazifeleri ise zaman içerisinde tevhit mertebelerini ${ }^{122}$ zevk ve idrak etmesi için tâlibi hazırlamak ve onu miracın idrak ve zevkine ulaştırmaktır. Müritlerinin miracı gerçekleştirmesini sağlamak gibi bir kudretleri ise bulunmamaktadır. ${ }^{123}$

Özemre mürşitleri üç gruba ayırır: Mürşid-i kâmiller, kâmil olmasa da toplumda önemli hizmetler icra eden ve sayıları oldukça fazla olan şeyhler ve tarikat eşkıyası olan yalancı şeyhler. ${ }^{124}$ Özemre'ye göre tâlibin mürşidin kemâli hakkında kıstas sahibi olmasının önemi büyüktür. Bu sebeple onun üzerinde en fazla durduğu meselelerden biri mürşid-i kâmilin vasıflarının neler olduğu veya neler olamayacağıdır. Burada Özemre'nin asıl meselesi mürşit oldukları iddiası ile ortaya çıkan pek çok sahtekâr arasında kâmil olanını ayırt edebilecek kıstaslar ortaya koyabilmektir.

Kemâl sahibi mürşitlerin özellikleri hakkında Özemre bir konuşmasında şunları söyler:

"Kendisine ihvan toplamak için davetçiler çıkarmak kemâl sahibi bir kişinin yapacağı bir iş değildir. Davet peygamberlere mahsus bir iştir. Velâyette ise davet yoktur, mürit olmak isteyen kişinin talebi vardır. Mürşid-i kâmil bu taleple kendisine gelen kişiyi hemen kabul etmeyip, bir müddet sınar ve bunlarda başarılı olanlara müspet cevap verilip, ihvan olarak kabul edilir. Bu yeteneğe sahip olmayanlara ise üzerlerine fazladan mükellefiyetler yüklenmek sebebi ile dünya ve ahiretleri rezil edilmez. ${ }^{125}$

Özemre`ye göre manevî eğitimini tamamlamadan kendini mürşid-i kâmil ilan eden kişiler, talebelerine maddî ve manevi pek çok zarar verirler. Ancak bu kemâl sahibi olmayan bir mürşide intisap eden kişinin sorumluluğunun kendisine ait olduğu gerçeğini değiştirmez. Ona göre böyle

120 Özemre,-Şahinler, Kâmil Mürşidlerin Mirası, s.330.

121 Özemre, Vahye Göre Akıl- İslâm'da Aklın Önemi ve Sinırı, s.170.

122 Tevhid Mertebeleri: Tevhîd-i Ef'al, Tevhîd-i Sifat, Tevhîd-i Zât, Cem, Hazretü'l-Cem, Cem'ul Cem ve Ehadiyet'tir.

123 Özemre-Şahinler, Kâmil Mürşidlerin Mirası, s.170,

124 Özemre, Şahinler, Kâmil Mürşidlerin Mirası, s.41

125 Özemre-Şahinler, Kâmil Mürşidlerin Mirası, s.40.

YIL: 5 SAYI: 9 


\section{$274 \cdot$ YALOVA SOSYAL BILIMLER DERGISI}

bir durum ile baş başa kalan sâlike gereken tek şey bu kişiyi terk ederek kendisine bir kâmil mürşit araması ve şeriat ile iktifa etmesidir. ${ }^{126}$ Çünkü farz olan böyle bir kimsenin peşinden gitmek değil, Hz. Muhammed in şeriat ve sünnetine riayet etmektir.» ${ }^{127}$

\section{Sonuç}

Ülkemizin tanınmış ilim adamlarından olan Prof. Dr. Ahmed Yüksel Özemre'nin tasavvufî hayatı başlıca üç döneme ayrılabilir. İlk gençlik yıllarındaki taşkın cezbe dönemi, bir mürşide intisabı ile devam eden müritlik dönemi ve sınırlı sayıda kişinin vâkıf olduğu mürşitlik dönemi.

Özemre, Halvetî-Uşşâkî tarikatında manevi eğitim almış bir sûfî olmakla birlikte onun tasavvuf anlayışında Melâmetî tavrın oldukça etkili olduğu söylenebilir. Özemre'nin 1925 yılında yürürlüğe giren tekke ve zâviyeler ile türbelerin kapatılmasına dair kanunu söz konusu yozlaşmanın önüne geçen bir gelişme olarak değerlendirmesi de bu Melâmî etkiyi göstermesi bakımından önemlidir.

Özemre'ye göre tasavvuf deyince esas kastedilen, kişide ilm-i ledün teessüs etmesi ve bu ilimle birlikte derin bir idrak seviyesine ulaşabilmesidir. Tasavvufun "şeriat" ve "akıl"ı ikinci plana attığını söyleyenlere şiddetle karşı çıkan Özemre'ye göre tasavvufî düşünceyi tam olarak idrak edebilmek de yüksek bir anlayış gerektirir.

Özemre'ye göre veli olmak için miraç şarttır. Miracını gerçekleştiren kişi zâhir realitesini aşarak bir üst hakikate ulaşır. Ancak zâhire karşı tutumunda daima temkin ile hareket etmelidir. Bu konuda en güzel örnek ise Hz. Peygamber'dir.

Özemre'ye göre, İlm-i Ledün denilen bilgi türünü kuşanacak olgunluğa ulaşmak isteyenlerin de kâmil bir yol göstericiye müracaat etmeleri gereklidir. Özemre'nin üzerinde en fazla durduğu meselelerden biri mürşid-i kâmilin vasıflarıdır. Onun asıl meselesi pek çok sahtekâr arasında kâmil olanını ayırt edebilecek kıstaslar ortaya koyabilmektir.

126 Özemre, Vahye Göre Akll- İslâm'da Aklın Önemi ve Sinırı, s.204.

127 Özemre-Şahinler, Kâmil Mürşidlerin Mirası, s.104.

YIL: 5 SAYI: 9 
Özemre'nin görüşlerini açıklarken, tasavvufî hayatın içinden biri olmasına rağmen, tasavvufî hayatta görülen aksaklıklar hakkında eleştiri yapmaktan geri durmayan tavrı, muhatabına tasavvufa dair objektif ve orijinal bir bakış açısı sunması, İslâm itikadının temel ilkelerine zarar vermeme hususundaki hassasiyeti, anlaşılması müşkül hususları herkesin anlayabileceği şekilde izah edebilmesi, kanaatimizce onun ilim adamı-sûfî kişiliğinden ve kıvrak zekâsından kaynaklanmakta, onu bu hususta özel bir konuma taşımaktadır.

\section{KAYNAKÇA}

AKMAN, Nuriye (röp.) "Ahmed Yüksel Özemre - Tasavvuf ile Taoizmin Anahtarı Bir" Sabah Gazetesi 8.10.2001 tarihli nüshas1

ALKAN, Ercan, (röp.), "Akıl Vahşi Bir Küheylana Benzer”, Keşkül Dergisi, Nisan 2005, S:4, s.60-67.

AYDIN, Mehmet S., "İnsan-1 Kâmil”, DİA, C. XXII, İstanbul 2000, s.330331.

AYVAZOĞLU, Beşir, “Özemre Hoca Kendi Cenazesini Nasıl Seyretti?”, Zaman Gazetesi, 03.07.2008 say1lı nüshası, s.7.

İZUTSU, Toshiko, Tao-culuk'taki Anahtar Kavramlar-İbn-i Arâbî İle Lao-Tzu ve Çuang-Tzu'nun Mukayesesi, Çev: Ahmed Yüksel Özemre, Kaknüs Yay., İstanbul, 2001.

ÖNGÖREN, Reşat, “Tarikat”, DİA, C.LX, İstanbul 2011, s.95-105.

ÖZEMRE, Ahmet Yüksel, Vahye Göre Aknl- İslâm'da Aklın Önemi ve Sinırı, Şule Yayınlar, İstanbul 2006.

----------, Üsküdar'da Bir Attar Dükkanı, Kubbealtı Yay., İstanbul 2014.

---------, Geçmiş Zaman Olur ki...,Kubbealtı Yay., İstanbul 2012

----------, Üsküdar'in Ü̧̧ Strlısı, Kubbealtı Yay., İstanbul 2009.

---------, Vahye Göre Akll- İslâm'da Aklın Önemi ve Sinırl, Şule Yay., İstanbul 2006. 
276 • YALOVA SOSYAL BILIMLER DERGISi

-----------, ve ŞAHİNLER, Necmeddin, Kâmil Mürşidlerin Mirası, İnsan Yay., İstanbul 2011.

ŞAHINLER, Necmeddin (Haz.), Çetrefil Bir Adam: Prof.Dr. Ahmed Yüksel Özemre, Kurtuba Kitap, İstanbul2012.

ULUDAĞ, Süleyman “Akıl (Tasavvuf)”, DİA, İstanbul 1989, C.II, s.246-247.

YILDIZ, Abdullah, "Bilge Bir Üsküdarlı: Ahmed Yüksel Özemre" Umran, S:101, İstanbul 2003.

(İsz.) röp., "Prof. Dr. Ahmet Yüksel Özemre ile Geçmişten Günümüze Bir Hasret Sohbeti...", Alttnoluk Dergisi, Ocak 1999, S:155, s.1115.

http:// ozemre.com

http://www.uskudarim.org 